\title{
STUDYING THE STOCKS MANAGEMENT OF A SMALL COMPANY OF THE SERVICES
}

\author{
Paulo Cesar Chagas Rodrigues \\ Insituto Federal de Educação, Ciência e Tecnologia de São Paulo \\ Campus Avaré \\ E-mail: paulo.rodrigues@ifsp.edu.br
}

Submission: 01/02/2013

Accept: 27/02/2013

\begin{abstract}
Many are the possibilities of intervention in the organizations so that they rationalize their process of production, and satisfy the necessities of their customers. Among these possibilities to be treated in this article it is the stocks management optimization, that is one of the great generators of waste, also, when badly managed, occults the majority of the management problems. Simple elements as tools for predicting demand, stocks control and classification systems, evaluation physicistfinancier system, layout, amongst other instruments, if correctly implanted and managed bring considerable benefits for the organization, increasing productivity and competitiveness. This research, has tried to restrict its focus, by studying the stocks management of a small of the computer science company located in the city of Bauru, State of Sao Paulo, which has an estimated population of 305.753 inhabitants, with approximately 1.338 industries, 7.094 commerce and 5.371 rendered company service.
\end{abstract}

Keywords: management of stocks; Logistics; Logistics of Plant; Layout. 


\section{INTRODUCTION}

The management stocks in the small computer science technical support companies in computer science is considered as a critical factor of the financial and operational point of view, starting of the premise that it is not made any study of adjustment, layout and for not having a definition of a replacement model.

So in view of the importance of this productive segment and the city, it has been decided to study the management stocks, for being one of the of great influence elements in the business administration performance.

Being the main objective of this research, to describe and analyze the system of management stocks in a small company of technical services in computer science, identifying its best practices and main difficulties, proposing at the end of the research, some improvement recommendations.

The accomplishment of this research aims to contribute with the services rendered section in computer science, generating knowledge in the better practices creation of a model that will speed up and make it more flexible to the operation, allowing an optimization of the management stocks and of the production. This attitude can make possible a larger competitiveness in the regional market.

This research is limited to a small company of technical service in computer science, where it will be studied the management stocks, focus the administrative management whose monthly revenue is about $R \$ 20.000,00$ and a dry functional staff with 12 employees.

Therefore, a qualitative research was accomplished with base in the study-ofcase methodology, because this kind of research basically worries about certain phenomenon understanding and interpretation, it has been planned here. The data collection instruments in the studied company happened through interviews, documents analysis and in loco visits.

In this article it is done a theoretical revised on material management systems, management production and logistics of plant transactions, so that this study be based on concepts.

\section{SYSTEMS OF PRODUCTION ADMINISTRATION (SAP)}




\section{INDEPENDENT JOURNAL OF MANAGEMENT \& PRODUCTION (IJM\&P)}

http://www.ijmp.jor.br

v. 4, n. 1, January - June 2013.

ISSN: 2236-269X

DOI: 10.14807/ijmp.v4i1.49

The concept Davis, Aquilano and Chase (2001, p. 25), define the production as being "[...] a group of components whose function is concentrated in the conversion of a number of inputs in some wanted" result. Therefore, the inputs are understood as the materials and the information, the resources comprehend people, machines and the necessary technologies to the production of the goods or services.

Those, the production involve people, ideas, machines, materials and information. For Plossl (1993), the materials and the information must be the center of attention for the organizations, because they are the two elements in the productive transformation that are more easily wasted, becoming cost for the organization. The information, if well used, can bring monetary profit and provide differentials to the organization.

The management the production is not only a simple process of production of certain quantities at the best time. Inside the production function we can classify the management decisions in strategies (long term), tactics (medium term), operational planning (short term) (DAVIS; AQUILANO; CHASE, 2001). These decisions will influence the form of planning, to programming and controlling the daily production. The production activities can be decomposed in a technical part (that executes the tasks) and another that offers support (the managerial) (ERDMANN, 2000). The PPCP - Planning, Programming and Controlling of the Production is introduce in this second part, projecting what should be done, working the system and exercising the right controls. For Welzel (2002), in general lines, the PPCP can be understood as a system of information that determines the directions of the production, accompanies the process realigning what has been programmed and exercising the respective controls. The PPCP involves several activities, but we will focus in this study to the project of the product and to the project of the process.

Corrêa and Gianesi (2001, p. 43) define, Therefore, some typical managerial activities that must be supported by SAP:

a) planning the future needs productive process capacity needs (qualitative and quantitatively), so that there is readiness to assist to the market at of compatible service level with the organization competitive needs; 
INDEPENDENT JOURNAL OF MANAGEMENT \& PRODUCTION (IJM\&P)

http://www.ijmp.jor.br

v. 4, n. 1, January - June 2013.

ISSN: 2236-269X

DOI: 10.14807/ijmp.v4i1.49

b) planning the bought materials so that they arrive at the moment and in the right quantities necessary to maintain the productive process working without harmful ruptures at the intended levels of their resources use;

c) planning appropriate levels of raw materials stocks, semi-finished and final product stocks in the correct places, so that to guarantee that the of the process uncertainties affect the level of service the least possible to the customers and the smooth factory operation;

d) programming production activities so that people and the involved equipments in the process be, in every moment, working on the right things, the ones with priority, avoiding, unnecessary dispersions of efforts;

e) being capable reacting in an efficient way at reprogramming activities well efficiently and fast pace in reprogramming activities when something runs badly in the process or when unexpected environmental situations happen;

f) providing information to other functions regarding the physical and financial implications of the activities, present and prospective, of the manufacture, contributing so that the efforts of all of the functions can be integrated and coherent; and

g) being capable of promising accurate periods to the customers and, later to accomplish them, even in dynamic environmental situations and, many times, difficult to foresee.

Corrêa, Gianesi and Caon (2001) comments that one of the main reasons of being the Production Systems of Administration is exactly to provide coordination in taking decisions. That means should be healed the problems of stocks redundancy that exist with the objective of solving problems of the lack of this coordination.

According to Slack, Chambers and Johnston (2002), one of the SAP functions of is the possibility to protect the production of the "environmental" uncertainties in offer and demand terms. A form of trying to minimize the environmental problems is maintaining stock of resources, being this input or output.

According to Welzel (2002), the production administration, its functions and techniques have direct relationship with the company objectives, being industrial or of services that is to be competitive. That can be translated as "(...) to be capable of 
INDEPENDENT JOURNAL OF MANAGEMENT \& PRODUCTION (IJM\&P)

http://www.ijmp.jor.br

v. 4, n. 1, January - June 2013.

ISSN: 2236-269X

DOI: 10.14807/ijmp.v4i1.49

overcoming the competition in those performance aspects that the focused market worth it better" (CORREA; GIANESI; CAON, 2001, p. 22). So we can understand as competitive advantages.

According to AEP (2004), thinking about the Productivity, it is verified, with frequency in those facilities occur facts that promote efficient and loss productivity being:

a) excess of people and raw material movement;

b) semi-finished and finished products, causing several disruption and increasing of breaking the risks and accidents, besides the production costs and time; and

c) the products have a very complicated productive course.

The basic idea of the simplification of the work corresponds to the elimination of everything that doesn't aggregate value to the product, in other words, everything that doesn't improve or doesn't transform the product and that increases its cost.

For Slack, Chambers and Johnston (2002), the physical arrangement of a productive operation worries about the physical location of the transformation resources. Putting into a simple way, defining the physical arrangement is to decide where to put all the facilities, machines, equipments and production person. The physical arrangement is one of the most evident characteristics of a productive operation because it determines its "form" and appearance.

Stevenson (2001) it comments on that the need to do a physical arrangement planning appears both during the project of new facilities and when projects of preexistent facilities are reformulated. The most common reasons for the physical arrangement project reformulation are the following ones:

a) the inefficiency of the operations (for instance, for high cost, for the existence of bottle mouths);

b) accidents, or risk to the physical integrity and to the safety;

c) change in the project and products or services;

d) introduction of new products or services;

e) changes in the production volume, or in the mix (composition); 
INDEPENDENT JOURNAL OF MANAGEMENT \& PRODUCTION (IJM\&P)

http://www.ijmp.jor.br

v. 4, n. 1, January - June 2013.

ISSN: 2236-269X

DOI: 10.14807/ijmp.v4i1.49

f) change in the methods or in the equipment;

g) change in environmental requirements or other of legal order; and

h) problems related with the personnel's morals (for instance, lack of face the face contact).

For Slack, Chambers and Johnston (2002), there are some practical reasons why the decisions of physical arrangement are important in most of types a production.

a) physical arrangement is frequently a difficult activity and of long duration due to the physical dimensions of the moved transformation resources;

b) the physical arrangement of an existent operation can interrupt its smooth operation, taking to the customer's dissatisfaction or to production losses; and

c) the physical arrangement (subsequent examined) is wrong, it can take to flow patterns excessively long or confused, stock of materials, customers' lines being formed along the operation, inconveniences for the customers, processing times unnecessarily long, inflexible operations, unexpected flows and high costs.

For Slack, Chambers and Johnston (2002) they classify in four basic types the layout: layout positional, layout by process, layout for product and cellular layout. This last one mentioned is the layout form that most impacts in the waste reductions under the of the Dry Production philosophy. Next there's an explanation of each layout type:

a) positional layout: it is used when the transformed materials are either very big, or very delicate, or even they would object to be moved;

b) layout by process: in this type of physical arrangement all the similar operation resources are maintained together. This layout type is usually used when the variety of products is relatively big. This type of layout is also known as functional layout;

c) cellular layout: in this type of layout the necessary resources for a peculiar class of products are contained in some way. In this physical arrangement the machines are dedicated to an exclusive group of parts; and 
INDEPENDENT JOURNAL OF MANAGEMENT \& PRODUCTION (IJM\&P)

http://www.ijmp.jor.br

v. 4, n. 1, January - June 2013.

ISSN: 2236-269X

DOI: 10.14807/ijmp.v4i1.49

d) layout by product: in this one the transformation resources are depicted in the specific sequence for better convenience of the product or of the product type.

This type of physical arrangement is also known as layout in line.

In the picture 01 Slack, Chambers and Johnston (2002) point out some of the most significant advantages and disadvantages associated to each type of physical arrangement.

\begin{tabular}{|c|c|c|}
\hline & Advantages & Disadvantages \\
\hline Positional & $\begin{array}{l}\text { - Mix flexibility and very expensive } \\
\text { product; } \\
\text { - Product or customer not moved or } \\
\text { disturbed; and } \\
\text { - High variety of tasks for the labor. }\end{array}$ & $\begin{array}{l}\text { - Very high unitary costs; } \\
\text { - Space programming or activities can } \\
\text { be complex; and } \\
\text { - It can mean a lot of movement of } \\
\text { equipment and labor. }\end{array}$ \\
\hline Process & $\begin{array}{l}\text { - High flexibility of mix and product; } \\
\text { - Relatively strong in case of stage } \\
\text { interruptions; and } \\
\text { - Relatively easy equipment and } \\
\text { facilities supervision. }\end{array}$ & $\begin{array}{l}\text { - Low use of resources; } \\
\text { - It can have big stock in process or } \\
\text { customers' lines; and } \\
\text { - Complex flow can be difficult to be } \\
\text { controlled. }\end{array}$ \\
\hline Cellular & $\begin{array}{l}\text { - Can give a good commitment } \\
\text { between cost and flexibility for } \\
\text { operations with relatively high } \\
\text { variety; } \\
\text { - Fast displacement; and } \\
\text { - Group work can result in better } \\
\text { motivation. }\end{array}$ & $\begin{array}{l}\text { - It can be expensive to configure the } \\
\text { current physical arrangement; } \\
\text { - It may require additional capacity; and } \\
\text { - It can reduce levels of resources } \\
\text { usage. }\end{array}$ \\
\hline Product & $\begin{array}{l}\text { - Low unitary costs for high volume; } \\
\text { - It gives the opportunity for } \\
\text { equipment specialization; and } \\
\text { - Customers' movement and } \\
\text { convenient materials. }\end{array}$ & $\begin{array}{l}\text { - It can have mix flexibility; } \\
\text { - Not very strong against interruptions; } \\
\text { and } \\
\text { - Work can be repetitive. }\end{array}$ \\
\hline
\end{tabular}

Picture 01: Advantages and disadvantages of the basic types of physical arrangement

Source: Slack, Chambers and Johnston (2002).

According to Severo Filho (2006), the kanban is a tool to operationalize the production system just-in-time, making possible to transform the production of being "pushed", that according to Moura (1989), it is represented by the traditional system of production, where orders are given in function of a certain demand expectation, that may be executed or not. Then, the production lots are transferred from the previous section to the subsequent one, independent on this having or not the need of receiving them, causing them, among other negative factors, an increase of the stock levels; and in "being pulled", that according to Moura (1989), it happens when the demand in certain section or cell is generated by the need of the section or following working cell. So, as the stock of finished products needs more products, it generates the production need of these by the work centers that supply it, for so it 
INDEPENDENT JOURNAL OF MANAGEMENT \& PRODUCTION (IJM\&P)

http://www.ijmp.jor.br

v. 4, n. 1, January - June 2013.

ISSN: 2236-269X

DOI: 10.14807/ijmp.v4i1.49

needs for this production receive the components produced in the previous sections and so forth, this way making possible that only the necessary components in certain moments be produced, in other words, pulling the production.

The kanban is a System Toyota of Production important of the element such, system that aims to the total elimination of the losses, however, they are not synonymous, being the kanban a technique to help the implement of those principles, being a self-control system in factory level, as it is illustrated the picture 02 .

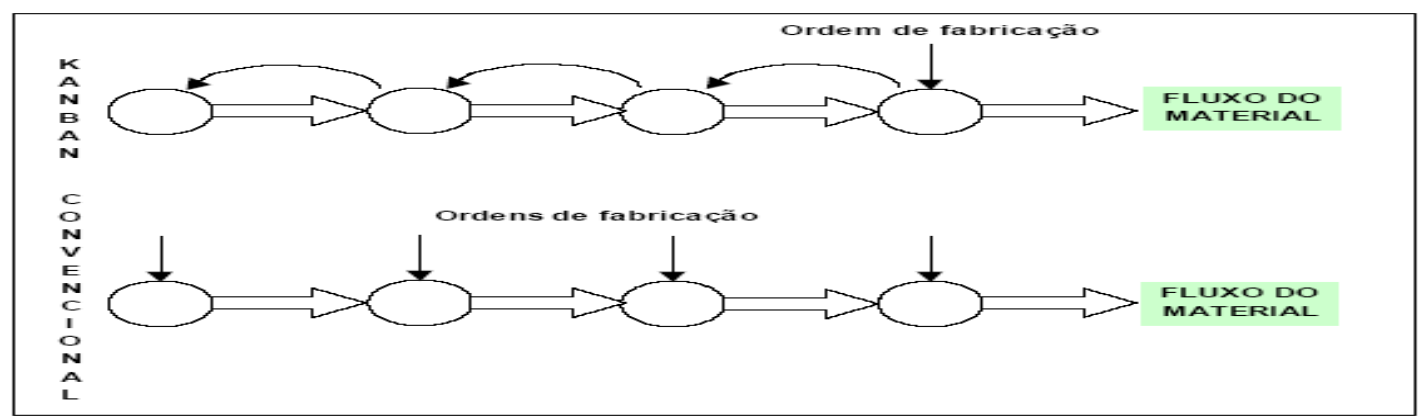

Picture 02: Planning Kanban X Conventional Source: Moorish (1989).

The kanban assumes all the production control functions below the monthly master program. All the production of the factory, the external suppliers flow of parts and the control of the of the factory inventory become of the supervision responsibility. The kanban is operated by the system employees production line, who possess the visibility and the deep knowledge of the immediate needs in the factory, to assist the needs of the master production program (ALBUQUERQUE; ARAÚJO; SEVERIANO FILHO, 1999).

\section{LOGISTICS}

According to Ballou (2001), it has been suggested that a logistics strategy has three objectives: (a) reduction of costs, where it is the strategy driven to minimize the variable costs associated to the movement and the stockpiling; (b) capital reduction, that is the directed strategy for minimization of the logistic system investment level; and (c) improvement in the service, that are strategies which usually recognize the incomes depend on the level of the supplied logistic service.

The author comments that the logistics will perform in the stock strategy, executing the planning and control, helping in taking of decisions on stockpiling and on the supplies program. To minimize the costs and stockpiling expenses, and to optimize the transference of the raw material of the productive process. To decide 


\section{INDEPENDENT JOURNAL OF MANAGEMENT \& PRODUCTION (IJM\&P)}

http://www.ijmp.jor.br

v. 4, n. 1, January - June 2013.

ISSN: 2236-269X

DOI: 10.14807/ijmp.v4i1.49

the quantities of the product that will be dealt, when, how to deal with them and from where to acquire them are some of the frequent concerns.

According to Severo Filho (2006), the logistics managers should constantly work with decisions regarding purchases, production and distribution. He mentions that some of the most important decisions are:

a) How many ask: every supply request should specify the requested quantity, basing upon expected future demands, supply restrictions, existent discounts and involved costs;

b) When to ask: the exact moment of emitting a new order is determined by the parameter of the request point, that depends on the supply lead time, on the expected demand and on the level of desired service;

c) Under what frequency to revise the stock levels: the stock levels can be revised continually or periodically, depending on the present technology and on the revision costs, among other factors;

d) Where to locate the stocks: if a company can stock their products in more than one installation, location decisions should be made, as for instance, to maintain finished products at small warehouses close to the customers or in a central warehouse, which depends on the distribution costs, service restrictions, time in which that the customers accept to wait, time of distribution, stock costs, costs of the facilities, etc; and

e) How to control the system: the usage of performance indicators and operation monitoring must be present to support corrective measures and contingency actions if the logistic system is out of control or operating with low performance.

The Logistics, according to Lima (apud BRAND; MULLER, 2004), can be divided into three macro-processes: supply logistics (Inbound Logistics), plant logistics and distribution logistics (Outbound Logistics). The supply logistics, according to Ballou (apud BRAND; MULLER, 2004) talks about the flow of products for the company instead of from this one, having as more important tasks in this segment: (a) the initialization and transmission of the purchase orders; (b) transports of the inputs / materials to the factory; (c) stocks maintenance. The plant logistics corresponds to the processes of internal provisioning of the manufacture; this way, 
INDEPENDENT JOURNAL OF MANAGEMENT \& PRODUCTION (IJM\&P)

http://www.ijmp.jor.br

v. 4, n. 1, January - June 2013.

ISSN: 2236-269X

DOI: 10.14807/ijmp.v4i1.49

related the this function, it can happen the formation of stocks and movement of materials and finished products among the production processes and stockpiling places, which will be given larger emphasis. In relation to the distribution logistics, the finished product can be stored in the later company itself or dispatched to external warehouses or distribution centers.

According to Garcia et al. (2006), SCM is the term used to describe the flow administration of goods and information along with a chain of supplies, passing through suppliers of raw materials, manufacturers, distributors, wholesalers and retailers, the final consumers have their demands served. The Picture 03 a typical chain of supplies.

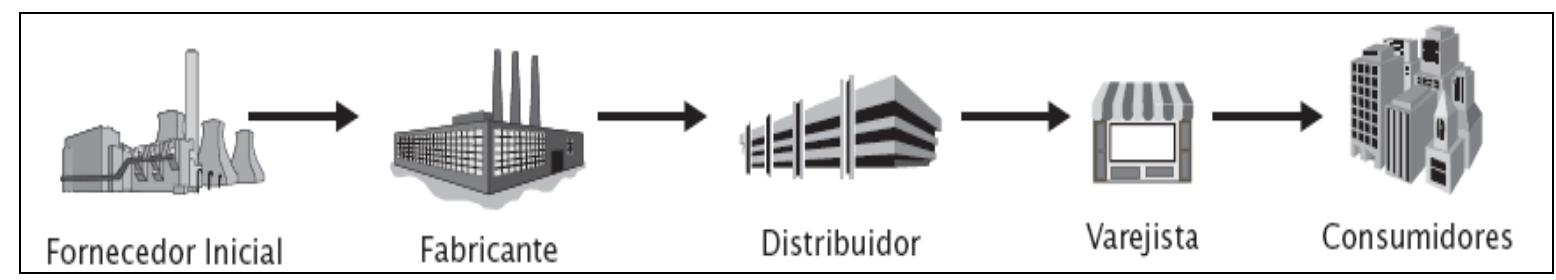

Picture 03: Illustration of a chain of supplies Source: Garcia, et al. (2006).

According to Ching (2001), a Supply chain is all effort involved in the different processes and business activities that create value in the form of products and services for the final consumer. Its management is an integrated form of planning and controlling the flow of goods, information and resources, from the suppliers to the final customer, this trying to manage the connections in the logistics chain in a cooperative way and for the benefit of all the involved ones.

Ching (1999, p. 6 and 68) clarifies that

Supply Chain management is a wider concept and strategically more important, that starts in the exit of the suppliers raw materials, it goes by the production, assembly, and it finishes in the distribution of the finished to products the customers; to formulate and to implement strategies based on the current customers' retention and obtaining new ones and to manage the chain in an effective way.

For Novaes (2001, p. 49), SCM is

the integration among the processes along the chain of supplies, that continues to be done in terms of flow of materials, of information and of money, but, now, the participant agents perform in unison and in a strategic way, looking for the better 
INDEPENDENT JOURNAL OF MANAGEMENT \& PRODUCTION (IJM\&P)

http://www.ijmp.jor.br

v. 4, n. 1, January - June 2013.

ISSN: 2236-269X

DOI: 10.14807/ijmp.v4i1.49

possible results in terms of reduction of costs, wastes, and aggregation of value for the final consumer.

Brand and Muller (2004, p. 21) mention that to know the nature of the logistics costs it is of great importance for the process of socket of decision related to the determination of the appropriate service levels to the consumers, visualization of opportunities for reduction of costs and improvements and for the evaluation and justification of investments in new technologies.

Bloomberg, Lemay and Hanna (2002) suggest that the costs be segregated in: direct and indirect, fixed, variable and semi-varied, unrecoverable (sunk costs) and increased or autcast ones. Each one of those costs reveals unique importance for taking of decisions in logistics and we will classify them according to the picture 04 .

\begin{tabular}{|l|l|}
\hline Purpose of the Information; & Classification of the Cost Logistics \\
\hline As for the relation with the object & Direct and Indirect \\
\hline As for the behavior before the activity volume & Pierced and Fixed \\
\hline As for the relation with the administration process & Controllable and non Controllable; \\
& Costs of Opportunity; \\
& Relevant costs; \\
& Unrecoverable costs; \\
& Increase or you Differentiate Costs; \\
& Occult costs (Hidden Costs); \\
& Standard Cost; \\
& Goal Cost; \\
& Kaizen Cost; and \\
& The Cycle of Life Cost. \\
\hline
\end{tabular}

Picture 04: Classification of the Logistics Cost as for the purpose of the information Source: Farias e Costa (2005).

According to Faria and Costa (2005, p. 69), "the logistics costs are the costs of planning, to implement and to control the whole entrance inventory (inbound), in process and of departure (outbound), from the origin point to the consumption" point.

For Dias (2005), the ABC curve is an important instrument for the administrator; it allows to identify those items that justify attention and treatment adapted as for its administration. The $A B C$ curve is obtained through the order, disposition of the items according to its relative importance.

\section{MANAGEMENT MATERIALS}

According to Slack, Chambers and Johnston (2002), stock is defined as the stored accumulation of material resources in a transformation system. Sometimes, the stock is also used to describe any stored resource. 
INDEPENDENT JOURNAL OF MANAGEMENT \& PRODUCTION (IJM\&P)

http://www.ijmp.jor.br

v. 4, n. 1, January - June 2013.

ISSN: 2236-269X

DOI: 10.14807/ijmp.v4i1.49

There are four stock types: the protection stock, the cycle stock, the anticipation stock and the channel stock, these concepts are also defined in the literature and widely used by the business practices.

Castro $(2005$, p. 22) highlights as the main mathematical models developed for the management stocks:

a) Economical: of developed by Harris in 1913, it was based on the logic that the great quantity to be produced is that one that has the lowest cost order simultaneously and to the stock;

b) Models of Scheduling: it can be translated as programming and it involves the usage of limited resources in a certain period of time to comply with the customers' request or the replacement of stocks;

c) Dynamic formation of lots: it has its origin in the economical lot and similar premises, with the exception that the demand doesn't need to be constant; and

d) Model probability: the probability models are much more sophisticated and complex and they take into account some of the deficiencies of the previous models. The most significant ones are the following:

- The news vendor's Model: this model tries to solve situations in which there is the need to determine the right amount to assist certain demand in a specific period, as point out Hopp and Spearman (apud CASTRO, 2005);

- The Model of continuous replacement of stock: in this model, the stock is monitored continually while the demand happens in a random way; when the stock reaches a certain degree " $r$ ", the request point, a "Q" production order (or request) is put;

- The Model of periodic revision of stock: in this model the stock is monitored in regular intervals and an order is put in two ways: with variable "Q" and enough to reach a degree of maximum stock fixed whenever there is analysis of the stock; combining the analysis interval with the request point, that is, only adding an order if the stock degree is equal or inferior to " $r$ ". Silver, Peterson and Pyke (apud CASTRO, 2005) point out that this model is 
INDEPENDENT JOURNAL OF MANAGEMENT \& PRODUCTION (IJM\&P)

http://www.ijmp.jor.br

v. 4, n. 1, January - June 2013.

ISSN: 2236-269X

DOI: 10.14807/ijmp.v4i1.49

particularly interesting for companies that don't use a computerized system

to control or to control several acquired items from the same supplier; and

- The Model of base stock: the logic is always to maintain the stock in the same landing. For so, the stock is supplied as the consumes happens, in such way to reestablish the objective degree, in other words, the amount of stock replacement is equal to the consumption.

For Silver, Peterson and Pyke (apud CASTRO, 2005), the classic models of management stocks should take into account three fundamental subjects: how often frequency is stock evaluation done? When to emit a request? And when should it be requested?

According to Arnold (2004), the stocks help to make the operation production to the in four ways:

a) They allow that operations with taxes of different production are carried out separately and in a more economical way. It is necessary to organize stocks among them, so that two or more operations of a sequence with different result taxes are carried out with efficiency;

b) They allow the leveling of the production and the organization of anticipation stocks for sales in the pick periods. This action results in:

- Lower costs with extra hour;

- Lower costs with recruiting and dismissals;

- Lower costs with training;

- Lower costs with sub-recruiting; and

- Lower demanded capacity.

They allow that the production maintains longer operations, which results in the following:

a) Lower preparation cost per item; and

b) The production capacity increase result from more time of use production resources usage the operations, instead of in the preparation. 


\section{INDEPENDENT JOURNAL OF MANAGEMENT \& PRODUCTION (IJM\&P)}

http://www.ijmp.jor.br

v. 4, n. 1, January - June 2013.

ISSN: 2236-269X

DOI: 10.14807/ijmp.v4i1.49

They allow the production to buy in larger quantities, which results in the reduction of the unit requests costs for and in discounts about the quantities.

For the author, all this has a price. The problem is to balance the investment in stocks with the following factors:

a) Service to the customers;

b) Costs associated to the change of production levels;

c) Cost of emission of requests; and

d) Transport costs.

According to Oliveira (2004), the waste can be defined as "any activity that doesn't join value to the product / service". It was identified seven types of wastes, the ones which are believed, to be applicable in several types of operations - in services and in manufacture: overproduction, time of wait, transport, process, movement, defective products and stock. To proceed, it will be made a brief explanation about the meaning of each one of them, according to the author:

a) Overproduction, to produce more than it is immediately necessary for the next process. Its elimination should be object of intense effort from the organization, because the processes of a production line should be balanced in such a way that it only proceeds to the production certain product in the amount and when the following internal customer request;

b) Time of wait, is the waste of expectation that happens when the production factors await to be processed: the companies tend to leave them stopped in function of the full use of the machines capacity and equipments of the previous processes many times it is produced addition much more than the next workstation has capacity to process;

c) Transport is the waste that happens as there are long distances to be traveled by the production factors along the process;

d) Process can happen as the developed stages and activities that don't add value continue to be executed due to the non-accomplishment of an effective analysis of which elements can generate costs and of the no-aggregation of the product value; 
INDEPENDENT JOURNAL OF MANAGEMENT \& PRODUCTION (IJM\&P)

http://www.ijmp.jor.br

v. 4, n. 1, January - June 2013.

ISSN: 2236-269X

DOI: 10.14807/ijmp.v4i1.49

e) Movement is the waste due to flaws in the project of the workstation: when the companies decide to execute the production process without to analyzing before the characteristics of the process thoroughly;

f) Defective products is the waste regarding the loss of production resources, time, storage, the consuming of equipments, credibility, etc; and

g) Stock happens when the company maintains unnecessary stocks, that mean investment losses and also of physical space.

The production wastes when no monitored or badly analyzed can generate quantitative and qualitative data conflicting, inducing onerous decision taking as for the stock. According to Ballou (2001), this monitoring can and must be also executed by the operation, so that it be minimized the damage.

According to Dias (2005), the systems of controls of stocks have the function of dimensioning controlling the stocks being an important and preoccupying theme. Being a constant and growing concern among the businessmen to discover recipes to reduce stocks without committing the productive process and without increasing the costs.

The concept $80-20$ is quite useful in the distribution planning when the products are contained or classified by their activities of sales or for their annual total sales values. The objective of that classification is to define systems of control of more appropriate stocks, establishing a more efficient total system in costs.

The steps for the application of the $A B C$ technique are the following ones (CORRÊA; GIANESI; CAON, 2001):

a) for each item to stock, to determine the total amount used in the previous year;

b) determine the average cost of each one of the stock items, using hard currency;

c) make calculations for each item in stock the total annual cost of usage, multiplying the average cost of the each item, lifted up in 2 , for the corresponding amount used in 1;

d) order in a list all of the items in decreasing value from the of established use value in 3 ; 
INDEPENDENT JOURNAL OF MANAGEMENT \& PRODUCTION (IJM\&P)

http://www.ijmp.jor.br

v. 4, n. 1, January - June 2013.

ISSN: 2236-269X

DOI: 10.14807/ijmp.v4i1.49

e) calculate the accumulated values of usage value for the whole list, in the defined order in 4;

f) calculate the determined accumulated values in 5 in relative percentage terms to the accumulated total value of the usage value for the total of the items;

g) Plot in a graphic the calculated values in item 6; and

h) define the three areas according to the inclination of the resulting curve: area, of great inclination; area B, of average inclination (around 45o); area C, of small inclination.

\section{Case Study}

In this research, trying to restrict its focus, in has been opted to study the management stocks in a small company which renders technical services in computer science, with average monthly revenue of $R \$ 20.000,00$ that whose headquarters is in the center-west area of the State of São Paulo of Brazil. This area is composed by 76 municipal districts and an approximate population of 1.650 .200 inhabitants. It has 7.196 industries, 22.773 service companies and 817 education centers approximately.

The studied company was founded in the 80' decade, by two entrepreneurs that work there more than 50 years in the segment and that are originated from of a great national computer science company. The studied company has about 12 collaborators and it has been if restructured so that can render a quicker service, flexible in a smaller cost for the final customer.

Basing in the exposed, the main objective of this research is to describe and to analyze; pointing the main positive aspects and the main deficiencies, the system of management stocks of a small company which renders technical services in computer science and that has its headquarters in the center-west area of the State of São Paulo, Brazil.

Nowadays, the company doesn't have any type ERP software, to integrate all of the areas of the company, to support the calculations of demand forecast, in the stock management, to monitor the production and to generate information to the administrative areas and help the direction in taking decision, as for the best practices that can be adopted. 
INDEPENDENT JOURNAL OF MANAGEMENT \& PRODUCTION (IJM\&P)

http://www.ijmp.jor.br

v. 4, n. 1, January - June 2013.

ISSN: 2236-269X

DOI: 10.14807/ijmp.v4i1.49

It has systems that work in a tight way, in other words, isolated, where there is not automatic change of information among the administrative area, financial and operational, being done through the net by messages, not having a control on the stock of parts, there is not a measurement of the values of stocks, the requests are made in an empiric way.

It has been noticed several times the delay in the service for not having a certain item in stock and it was verified a high index of rotation of this item later, in compensation some items that are already obsolete or that have a rotation index below the expectation, are present in high quantities.

The company also has a serious problem in the physical layout of its structure, where it has been executed some improvement on realigning the departments and of flow of parts and equipments, because of certain times during the day it is noticed a personnel traffic jam and bad usage of the specialized labor, as it can be observed in the Picture 05, this is the old layout.

The stock of parts and equipments is in an appropriate place, because the technicians have free access and many times it has been noticed the non execution of the rules for the usage of the parts in equipments in maintenance and even in the substitution and devolution of the backup equipments.

The logistics in the calls service is done without any rule and that is generating an excess the numbers answered call and in the time of displacement by some technicians it was also observed in a sporadic way the displacement of more than a technician for the same customer with the intention of assisting different calls.

Something else noticed and a very critic one is that the technician decides who he will assist first, having as a parameter personal interest, the relationship degree and not the established priority for the direction and nor even having a rational and economical displacement. 


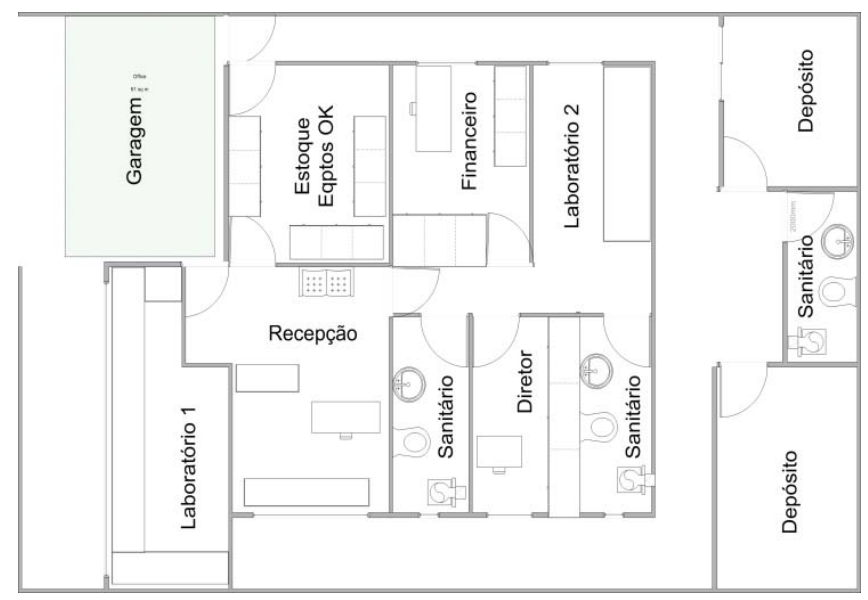

Picture 05: Old layout of the company

There is not on the part of the management of the company any pattern type for calculating a demand forecast of parts and technician calls, that after a brief study has detected a very high cost from the purchase of the parts, because the same ones are bought in small lots, not allowing a better negotiation of the values and having very high expenses with freight.

The company has been losing important customers, because is service cost is high for the market pattern, the high lead time between the open call and the problem solution, the bad distribution of the calls, the lack of attendance of the assisted call among other factors.

\section{Recommendations}

It is necessary that the company go by a restructuring of their processes, so that it is competitive to the level costs, agility and flexibility again, for that it is proposed that an alteration in the layout of the plant, in the management stocks, in the service logistics to the internal and external customer, of $\mathrm{RH}$, become among other things.

It should be initiated the process of normalization of the processes, where all of the processes should be tabulated and given priority levels, so in a second step they can be written in a clear and objective way, where every new company employee can read and understand how the processes work.

A document of the information safety politics should be elaborated, in which all of the employees should sign in a copy when they are recruited and it has to be together with their documents in the company and a copy with, where it should consist their rights and duties and how to proceed in case of contingency. 
INDEPENDENT JOURNAL OF MANAGEMENT \& PRODUCTION (IJM\&P)

http://www.ijmp.jor.br

v. 4, n. 1, January - June 2013.

ISSN: 2236-269X

DOI: 10.14807/ijmp.v4i1.49

The restructuring process can begin by the alteration in the layout of the plant, where the reception would be in the entrance of the company, so the customer does not have direct access to the laboratory, because he would have to go by the receptionist, being the first laboratory of printers, because it is an equipment that can be very heavy and high cost, the second laboratory would be the one of microcomputers and notebooks, for they are lighter and of easing handling, the financier and the stock can stay at a single room, because the employee doesn't need the whole the space and in this way you can improve in the company customization because it the same employee has the appropriate trainings he can manage the stock of parts, these alterations can be seen in the Picture 06.

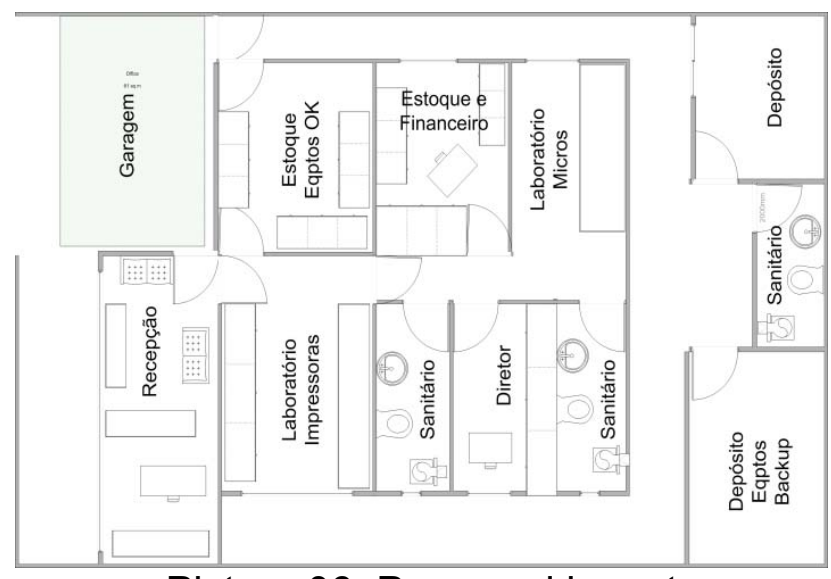

Picture 06: Proposed layout

In the existent deposits, it one of them is organized to receive all of the backup equipments that the company has, it will allow the customization the space in the company and (in the other it can be) the equipments without repairs, that will be recycled and this area will be transformed in a new future in to at another laboratory, in case it is necessary.

The management stocks was normalized following the $A B C$ model, where Côrrea, Gianesi and Caon (2001), define some steps for as application and in the ABC classification, was dismembered so that they could adopt other models according to the degree of importance of the product, for instance: in the products classified like "C", the classification of two drawers was used, but in the products classified like "B" it was used the classification of maximum and minimum and for the products classified as "A" it was adopted the Economical Lot of Purchase (LEC) model. 
INDEPENDENT JOURNAL OF MANAGEMENT \& PRODUCTION (IJM\&P)

http://www.ijmp.jor.br

v. 4, n. 1, January - June 2013.

ISSN: 2236-269X

DOI: 10.14807/ijmp.v4i1.49

The depreciation of the stocks must be made by the method of the constant shares, because the inflation is controlled and in acceptable levels, the calculations of the depreciation should happen every six months such way, allowing better vision of the earnings and to trying to balance the costs.

The establishment of an ERP system control the callings, that has integrated stock control, customers' register, technicians and suppliers, emission of service receipt and of sale, bills to pay and to receive allow to accompany the technician's productivity, for equipment, contract and piece model, allow to visualize the report of calls of the equipment and who has assisted the occurrence and gave its solution, if it is contract equipment, warranty or detached.

The system should contemplate calculations of the part stocks depreciation and existent backup equipments in the company, because having stock of certain parts and equipments, level can mean loss, for the most varied reasons and even to improve the negotiation, the level of negotiation of the products either to the suppliers or to the customers.

With the establishment of the system, the management stocks can be normalized, so that can assist the specifications that were previously undefined, to inform which is the rotation of each product, the economical lot of purchase, which should be the minimum stock and of safety, period of delivery to the supplier with minimum, medium and the high price.

Diming to improve the quality in the system service it should anticipate when the call was opened, which was the Lead team for the service and solution, it should have parameters about the period of service and solution of the problem, what a type of customer and priority, which technician should assist or should make the control of the taken parts of the stock for service in the laboratory and in field, crossing information with the calling; about the closing of the calling, the part it should be given their part with defect or the one that was removed them the stock.

With the reception in the entrance, the technicians' agglomeration in the laboratories can cease, because who will assist the field, receives call on the reception and only has to request the necessary parts for the service and doesn't need to go back to the company. 
INDEPENDENT JOURNAL OF MANAGEMENT \& PRODUCTION (IJM\&P)

http://www.ijmp.jor.br

v. 4, n. 1, January - June 2013.

ISSN: 2236-269X

DOI: 10.14807/ijmp.v4i1.49

The receptionist will have the function of filtering the customers' access to the laboratories, to the financial area, to the director and technical areas as well she will also (certain period of the day) do the attendance of the services, like calling the customers and evaluating the service, the attitude and the degree of knowledge passed by the technician.

The receptionist should try to know the course of the internal calls and maintain the customer always informed on his/her equipment and it some alteration there was been in the prevision forecast of the occurrence solution. she/he should also call after one week the customers have token their equipments to the company to know it everything is normal, if there hasn't been any occurrence after the equipment removal, if she/he is satisfied with the accomplished service.

About the arrival of the equipment with problems in the reception of the company, it should be opened the calling, generated the report and identification label, so that there is control on the equipments that are in the company.

As for the service logistics to the external customers, it should be thought about creating areas for each technician, so as the calling is opened it can be immediately sent to the technician and in case are of the technicians doesn't have many calls they should be divided in that moment, the area of who has more calls and that it is close to his/hers.

In the technical calling there should have, traveled number of the kilometers driver, time of displacement among the calls, so that it can be made the costing of each call, through the system, where there will be the cost hour and the technician and value of the fuel, in such a way to measure how must productive the technician really was audit the really had the lowest displacement cost. In the laboratory services, it should be combined priorities about: arrival order, the customer's level, emergency degree, etc.

It should also have at least a technician that has a degree of larger knowledge to assist the company customers vip, these allowing a larger fidelization of the customer either the company and a more personalized service.

But for that it should be delegated for somebody the powers to define what should be assisted first, this person should have certain degree of knowledge of the area, about the types of equipments that will be assisted and the volume of calls by 
INDEPENDENT JOURNAL OF MANAGEMENT \& PRODUCTION (IJM\&P)

http://www.ijmp.jor.br

v. 4, n. 1, January - June 2013.

ISSN: 2236-269X

DOI: 10.14807/ijmp.v4i1.49

technician, so that nobody gets overloaded and it doesn't cause stress for the customer and the technician.

But about the management the human resources, it should be thought about a company that has experience in doing the recruitment and personnel's selection and business, as well as in promoting the employees' recycling, through technical trainings, labor training, professional attitude, about the legislation, among others. To promote reward for productivity and commitment.

In the area of management human resources it should have an attendance of the employees' productivity, because this attendance should support the decisions of the direction, it should also have a half-yearly program on the employees' evaluation 360th.

All the problems that involve employees should be treated directly by the human resources and the period for the meeting with the employee should be at the most of 1 week, with the complainer on part return the first useful day after the meeting.

Another duty of the human resources will be the attendance of the employee's health, where it should maintain a registration of the vaccination notebook, the disease and accident, dismissals the reincidences that could be extended to the relatives that live with the employee.

\section{CONCLUSION}

If the company hadn't started begin a fast restructuring process, it could have had serious financial problems, because the services were decreasing, the purchases of products were badly managed, the logistics service was very bad and without any criterion, it didn't possess any parameter type on the accomplished services, there were not notion of time of displacement and service.

But it has much to get better and grow, therefore the market competes with this type of service and as the director had noticed that he was having a down fall in the revenue of the company, he decided to begin an entire restructuring of the company in the second semester of 2006 with the recruiting of a consultancy group to detect the critical points inside the processes of the company and that needed an immediate action.

As it was shown in the previous topics the lack of a system and the layout of the company were some of the critical points and where it was decided to work 
INDEPENDENT JOURNAL OF MANAGEMENT \& PRODUCTION (IJM\&P)

http://www.ijmp.jor.br

v. 4, n. 1, January - June 2013.

ISSN: 2236-269X

DOI: 10.14807/ijmp.v4i1.49

immediately, the layout of the company could be altered soon by the end of the year between Christmas and the New Year, when the company decided to stop with most of the job and to do all the restructuring and consequently the acquisition of their own system for technical support companies.

With this reorganization of the departments and the introduction of the system it was also possible begin an inventory of the stock of parts, and backup equipments, being made the registration in the system, with the respective quantities and values and equipments that were borrowed.

The Kanban label was instituted for all of the equipments that entered the technical support, parts that were used in these equipments and the record in the system that was made by the company's receptionist who got in touch with the customer informing him/her the course of the maintenance.

The management supplies, being done through the system that has the module of supplies, where: the economical lot of purchase, minimum stock, stock of safety, the $A B C$ curve for product and product line, the medium period in stock of each product, the percentage of profitability for product line, etc.

So is defined the first information could be generated the accounting it was requested all of the 2006 purchase and sale receipts and also from the second semester of 2005 , this way they were recorded in the system, so that some statistical values could be measured on the rotation of the products.

When certain product reaches minimum stock of is initiated a quotation process with the registered suppliers, where the responsible for the stock and finances already knows which is the best purchase option and immediately makes the purchase request, when the purchase request is superior to a certain value the request is sent to the director, that will give the final word.

There was a reduction in the freight costs, and a larger rationalization in the purchase of products, reduction in the number of intercity connections for the suppliers, less work as for the registration of the requests and the opening of callings.

By now the measurements are being made monthly, so that it can detect and to work the deviations, in such way to correct the created parameters. The director of the company seems to be very favorable to the changes that are being done and opened to new changes that are being planned. 
INDEPENDENT JOURNAL OF MANAGEMENT \& PRODUCTION (IJM\&P)

http://www.ijmp.jor.br

v. 4, n. 1, January - June 2013.

ISSN: 2236-269X

DOI: 10.14807/ijmp.v4i1.49

The director already has glimpses as a possible and measurable goal the certification of ISO $9001: 2000$ for the year of 2008 , because with all the restructuring that is being done, the company's already reaching satisfaction levels and quality better day by day having a very comfortable atmosphere of work for all of the employees.

It has been made the collection of information so that until the beginning of the second semester of this year the company will have a growth of $15 \%$ in revenue and it can make new trainees' recruiting, as form of generating professional technicians.

However, this research doesn't end all the administration possibilities, because as the own case study demonstrates, in spite of having common challenges to all companies, there are also specificities in function of the adopted strategies in each company or even in function to the characteristics of its operation.

\section{REFERENCES}

AEP (2004), Associação Empresarial de Portugal. Manual de Formação:

Produtividade e Inovação: Programa Formação PME. Lisboa: Câmara de comercio e indústria.

ALBUQUERQUE, M. E. E.; ARAÚJO, M. S. G.; SEVERIANO FILHO, C.(1999) A lógica do sistema kanban na indústria calçadista: análise de um sistema de programação da produção de solados e palmilhas. In: ENCONTRO NACIONAL DE ENGENHARIA DE PRODUÇÃO, 19., 1999, Rio de Janeiro. Anais... Rio de Janeiro: UFRJ. 1 CD-ROM.

ARNOLD, J. R. T. (2004) Administração de materiais. São Paulo: Atlas.

BALLOU, R. H.(2001) Gerenciamento da Cadeia de Suprimentos. São Paulo: Bookman.

BLOOMBERG, D. J.; LEMAY.; S. HANNA, J. B. (2002) Logistics. New Jersey: Prentice Hall.

BRAND, F. C.; MULLER, C. J. (2004) The ABC Costs Methodology applied to Logistics. Opinio: Revista de Ciências Empresariais, Políticas e Sociais: especial logística, 12, Canoas: Ulbra.

CASTRO, R. L.(2005) Planejamento e controle da produção e estoques: um survey com fornecedores da cadeia automobilística brasileira. Dissertação (Mestrado em Engenharia de Produção)-POLI/USP, São Paulo.

CHING, H. Y.(2001) Gestão de estoques na cadeia de logística integrada: Supply chain. 2 ed. São Paulo: Atlas.

CORRÊA, H. L.;GIANESI, I. G. N.; CAON, M. (2001) Planejamento, programação e controle da produção. 4 ed. São Paulo: Atlas.

DAVIS, M. M.; AQUILANO, N. J.; CHASE, R. B. (2001) Fundamentos da administração da produção. 3 ed. Porto Alegre: Bookman. 
INDEPENDENT JOURNAL OF MANAGEMENT \& PRODUCTION (IJM\&P)

http://www.ijmp.jor.br

v. 4, n. 1, January - June 2013.

ISSN: 2236-269X

DOI: 10.14807/ijmp.v4i1.49

DIAS, M. A. P. (2005) Administração de materiais: princípios, conceitos e gestão. 5 ed. São Paulo: Atlas.

ERDMANN, R. H. (2000) Planejamento e controle da produção. Florianópolis:

Papa-livros.

FARIA, A. C.; COSTA, M. F. G. (2005) Gestão de custos logísticos. São Paulo: Atlas.

GARCIA, E. S.; et al.(2006) Gestão de estoques: otimizando a logística e a cadeia de suprimentos. Rio de Janeiro: E-papers.

MOURA, R. A. (1989) Kanban: A Simplicidade do controle da Produção. São Paulo: Instituto de Movimentação e Armazenagem de Materiais, IMAM.

NOVAES, A. G. (2001) Logística e gerenciamento da cadeia de distribuição. Rio de Janeiro: Campus.

OLIVEIRA, O. J. (org). (2004) Gestão da qualidade: tópicos avançados. São Paulo: Pioneira Thomson Learning.

PLOSSL, G. W. (1993) Administração da produção: como as empresas podem aperfeiçoar suas operações para tornarem-se mais competitivas e rentáveis. São Paulo: Makron Books.

SEVERO FILHO, J. (2006) Administração de logística integrada: materiais, PCP e marketing. 2 ed. Rio de Janeiro: E-papers.

SLACK, N.; CHAMBERS, S.; JOHNSTON, R. (2002) Administração da produção. 2. ed. São Paulo: Atlas.

STEVENSON, W. J. (2001) Administração das operações de produção. 6 ed. Rio de Janeiro: LTC.

WELZEL, E. (2002) O comércio eletrônico e o setor industrial: estudo de caso da Cremer S.A. In: SIMPÓSIO DE ADMINISTRAÇÃO DA PRODUÇÃO, LOGÍSTICA E OPERAÇÕES INTERNACIONAIS, 5., São Paulo. Anais... São Paulo: FGV, 1 CDROM. 